\title{
A partilha da voz em Pascal Quignard
}

\author{
Verónica GaLíndeZ \\ Univeridade de São Paulo
}

Resumo

Este artigo tem por objetivo identificar e dar a ler o que Pascal Quignard propõe como música em Butes, por meio da retomada do texto publicado em 2008 e do conjunto de manuscritos publicados em Sur le désir de se jeter à l'eau, de 2011. Este caminho tem por ponto de partida a obra de Pascal Quignard, mas pretende realçar o ato político que ela implica, o político tomado aqui no sentido de uma partilha do sensível como proposta por Jacques Rancière e que funda a política da literatura.

\section{Résumé}

Cet article a pour but d'identifier et de donner à lire ce que Pascal Quignard propose comme musique dans Boutès en ayant pour point de départ la publication de l'ensemble de ses manuscrits, publiés dans Sur le désir de se jeter à l'eau, de 2011. Ce parcours trouvera son point de départ dans l'oeuvre de Pascal Quignard, mais prétend en souligner l'acte

Palavras-chave

Voz;

música;

Pascal

Quignard. politique qu'elle implique, le politique étant pris ici au sens d'un partage du sensible tel que proposé par Jacques Rancière et qui fonde la politique de la littérature.

Mots-clés

Voix; musique;

Pascal Quignard. 
É nessa condição que Butes, o mergulhador das Argonáuticas de Apolônio de Rodes, vingado aqui por Pascal Quignard, se torna o eixo de uma meditação sobre a música; sobretudo, de uma meditação sobre as origens da música, sobre a música originária em sua relação com a escritura, também com a leitura e a dança.

Antes de desenvolver o que motiva esta reflexão sobre a voz em Butes de Pascal Quignard, cabe retomar alguns elementos centrais de sua obra, ainda muito desconhecida entre nós. Pascal Quignard foi estimulado pelo poeta Paul Celan para traduzir o poema apocalíptico, "Alexandra", de Licofronte, por muito tempo considerado um poema hermético e intraduzível (pelo poeta Boissonade). Estabeleceu as obras completas de Maurice Scève, poeta renegado do século XVII. Trata-se, por sinal, de um século que interessa Pascal Quignard de maneira central. Interessa-se por esse momento de constituição de uma língua nacional e suas lutas internas ao longo desse barroco francês, marcado pelas guerras de religião, e que ele resume na fórmula, retomada de Stendhal e deslocada no tempo, "J'aimerais être lu en 1640".

Depois da publicação da tradução e de alguns tratados, é contratado pela editora Gallimard como leitor de originais, cargo ao qual é convidado graças à influência do escritor Louis-René des Fôrets, cuja obra analisa no ensaio intitulado "Le voeu de silence". Seu ensaio sobre Sacher Masoch, L'être du balbutiement, é muito elogiado por Gilles Deleuze, que o usa como base de sua proposta de prefácio para a tradução francesa na "Apresentação de Sacher Masoch".

As figuras esquecidas - pelas instituições, pelas normatizações linguísticas e culturais, pelos diversos discursos que constroem nosso repertório cultural - nos conduzem a uma questão diretamente relacionada com a morte (retomaremos isso em Butes) e são de certa forma "vingadas" na sua escritura. Mas veremos que se trata de muito mais do que simplesmente reescrever a história. Trata-se - muito rapidamente aqui agora - de nomear os restos de um passado aparentemente enterrado no sujeito que escreve, no seu corpo, mas também em sua potência enunciativa. Assim, o leitor se depara, amiúde, com temáticas, enumerações, coleções, contos, romances, relacionados ao lugar possível da voz na tensão permanente entre a experiência do vivido e as duas experiências impossíveis de narrar: o próprio nascimento e a própria morte.

Aproximamo-nos da morte. Pascal Quignard divide a vida na terra em três reinos, um pouco na tradição católica: o Primeiro Reino, aquele que precede o nosso nascimento e que termina no momento que "caímos no mundo", como ele diz, e que guarda a famosa "cena originária", é central em sua escritura, e ultrapassa a literariedade da cena exclusivamente ligada ao engendramento. Depois, temos o Segundo Reino, no qual vivemos, no qual nosso corpo se faz presente e que nos permite enunciar. É o reino no qual o sujeito que escreve se enuncia. Finalmente, temos o Último Reino que guarda a outra imagem que nunca veremos: a imagem de nossa própria morte. 
O presente se constitui para ele, assíduo leitor de Santo Agostinho, como esse tempo/espaço, esse universo de relações, marcado por essas duas ausências, em busca dessas imagens ou por elas obcecado. A morte está dos dois lados: daqueles que vieram antes e daquilo que nos acometerá. $\mathrm{O}$ corpo carrega o que restou do passado e vive na tensão, no pânico, da sobrevivência animal e instintiva.

Assim, não é um acaso se no projeto chamado "Último Reino" temos títulos como $A s$ sombras errantes, Sobre o outrora, Abismos, As paradisíacas, Sordidíssimas, A barca silenciosa, Desmontados, Morrer de pensar. Coleções de sobras, de sombras, de mortos, de decaídos.

A questão da morte começa a se delinear aos poucos: no que diz respeito à escritura de Pascal Quignard, tal como ele a propõe, haveria uma relação entre a morte e o ato de narrar? De que natureza é então essa relação com a morte? Qual é o lugar da narrativa, pensada aqui estritamente enquanto ato de narrar? Qual a voz implicada nesse ato?

\section{Butes}

São duas as cenas originárias deste texto: o mergulhador de Paestum e o homem de Lascaux.

São duas cenas que evocam a morte: o homem de Lascaux caindo de costas, com o grande bisão acima da cabeça, e o mergulhador do cabo Leucate, o mergulhador de Paestum, que pula no mar e para a morte.

Essas duas cenas adquirem, no desenho autógrafo, contornos de cenas de sonho, já que não se trata nem de cópia nem de reprodução das imagens que conhecemos, mas das imagens tais como elas se apresentam para aquele que escreve. A essas duas cenas, juntam-se muitas outras, dessa vez literárias, e relacionadas à morte e à perda.

Outra cena é a que dá título ao texto: Butes, o argonauta, que pula do barco, que abandona seu posto de remador e se joga ao mar. Em Apolônio de Rodes ele é tratado como “infeliz", porque morre. Se afoga no mar.

Butes só aparece duas vezes, em dois versos de Apolônio. Mas, para Pascal Quignard, essa cena, associada a outras, vai desencadear uma meditação - um bordado, ${ }^{2}$ como ele gosta de dizer -, uma atualização de uma questão central para seu grande projeto de escritura: nossa relação com a origem e com a morte.

Eis a lista de referências que passam a gravitar em torno de Butes nos manuscritos:

"Escrever Butes cf Rancé

Diana

Orfeu

Sereias" (Versão 3 Folio 5)

Trata-se de Chateubriand, Klossovski, Blanchot e Kafka. 
O que está em jogo aqui?

Por que Butes é um infeliz para Apolônio? Por que morrer é ser infeliz?

Porque se ele morre, não pode narrar. Butes não narra.

Por que Ulisses narra? Porque se aproxima da morte - mas não se joga, não atende ao chamado. Ele retorna e por isso pode narrar. Ele sabe que, se criar o ponto surdo e abrir as orelhas e os ouvidos ao canto das sereias, esse chamado erguerá o corpo. Mas ele precisa voltar, contar, narrar. Por isso se amarra. Quignard desenvolve a relação entre amarrar, atar, desatar e contar ao recuperar a origem da palavra "análise":

\begin{abstract}
A primeira vez que a forma 'análise' aparece no mundo grego se situa no verso 200 do canto XII da Odisseia de Homero. Ulisses é desamarrado (...) de suas amarras (...) por Euríloco e Perímedes, cujas quatro orelhas estão tapadas pela cera previamente extraída de um favo de mel com uma faca de bronze. ${ }^{3}$
\end{abstract}

Isso tem outras implicações em literatura, obviamente, que têm a ver justamente com a criação - a forja - do lugar do narrador. O narrador vai nos falar da morte para que não tenhamos que vivê-la. No entanto, para Quignard, isso significa que não nos jogamos no mar, não mergulhamos de verdade na dor.

Está em jogo nossa relação com o que Pascal Quignard chama de Perdida, essa cena perdida, quando ainda não estávamos separados, antes de Chronos começar a nos comer e nos levar em direção à morte. A vida pós-uterina só tem uma tendência: a morte.

O leitor de Butes parece ser colocado em um lugar de identificação com o argonauta que se joga ao mar, que decide ouvir o canto das sereias, da música e da forma como ela "avança" em nosso pensamento, a maneira como nos permite um conhecimento sobre o mundo, sobre a dor. No entanto, esse "avançar" no pensamento não parece se traduzir como logos, ou produção de discurso sobre o pensamento, mas como experiência, afeto, no e pelo corpo. O corpo do leitor, ainda assim, está protegido e não vai se lançar na morte. Interfere, então, outro universo sensível para a construção dessa experiência: a relação entre corpo e música. A música produziria esse soerguimento do corpo na e pela sua experiência com a dor e com a tristeza.

"Quem tem coragem de ir ao fundo do mundo da tristeza? A música."4

Para isso, a escritura quignardiana fará com que o outrora da música irrompa, se distenda. Trata-se da "música antes da música":

A música que está lá antes da música, a música que sabe se 'perder' não tem medo da dor. A música especialista em 'perdição' não precisa se proteger com imagens ou premissas, nem precisa se iludir com alucinações ou sonhos. Por que a música é capaz de ir ao fundo da dor? Porque nela jaz.

$\mathrm{O}$ canto que se realiza antes da língua articulada mergulha - simplesmente mergulha, mergulha como Butes mergulha - no luto da Perdida." 5

O canto, esse canto animal presente em Butes, não articulado, remete à origem. A voz aqui é o grito originário, o chamado de algo que nos antecede e não uma prospecção. É o chamado daquilo que chegou até nós e de que nosso corpo é resto, rastro, testemunha. Uma primeira leitura, exclusivamente baseada no texto publicado, propõe um universo textual que 
evoca tempos diferentes (Apolônio de Rodes, Schubert, o órgão da família Quignard, abril/maio de 1968), lugares diferentes (Grécia, Itália, Japão, Le Havre) e campos artísticos diferentes (a música, a dança, a imagem, a escritura, a leitura). O leitor identifica a iniciativa fragmentária típica de Quignard, à qual tem se habituado a partir do início do projeto intitulado "Último Reino", mas também presente em obras anteriores tais como Une gêne technique à l'égard des fragments, La haine de la musique, etc. Trata-se de uma leitura meditativa, que propõe relações sensíveis, implicando o sensível daquele que escreve e que ele decide compartilhar com seu leitor, produzindo um ato, uma leitura múltipla, uma leitura mobilizadora.

A epígrafe deste artigo retoma a empreitada enunciada no texto publicado: escrever um "último pequeno livro sobre a música". Trata-se do oitavo livro dedicado à música. A empreitada se propunha a saldar uma dívida para com aqueles que o antecederam, para com aqueles a quem devia o fato de ter se tornado músico. É um pequeno livro que "chama", que invoca, os outros sete escritos anteriormente, mas que também invoca todos os livros lidos por aquele que escreve.

Entretanto, é só ao percorrer a edição dos manuscritos preparatórios de Butes que o leitor descobre que o texto responde, originalmente, a uma proposta bem específica, intitulada "A música como arte do pensar", no âmbito de um debate organizado pelo jornal francês $L e$ Monde. O texto, que num primeiro momento responde a essa questão, ganha forma, se desenvolve, sendo retomado, dois anos mais tarde, em uma incursão que acaba tocando a experiência pessoal do Eu que escreve, de sua relação com a música e com sua tarefa de músico.

A essa primeira empreitada se acrescenta uma segunda: a de conservar seus manuscritos de trabalho, atendendo a um pedido de uma pesquisadora: Irène Fenoglio. A essa segunda empreitada, acrescenta-se uma terceira: a publicação do conjunto de manuscritos de trabalho enviados à geneticista, organizados e repertoriados, atestando um processo que produz um efeito naquele que escreve, uma reflexão sobre seu próprio trabalho - ele se confessa "desenganado" - e suas operações de escritura e de leitura. A reflexão sobre a música como arte do pensar se vê desdobrada em meditação sobre a escritura, sobre o desejo e sua pulsão invocante, sobre a dança, sobre o corpo. A música ali pensa ao mesmo tempo em que a escritura faz ato.

É justamente essa música que avança no pensamento e que faz o pensamento avançar que está colocada como centro de uma partilha com o leitor. É o que chamei a partilha da música e que associo à "partilha do sensível" proposta por Jacques Rancière em La mésentente: uma nova distribuição das partes, uma nova configuração do espaço da música na relação com a escritura por meio do desejo e do corpo a partir daquilo que não parece constituir-se como consenso na escrita: o chamado da voz (das Sereias, neste caso). É a razão pela qual é importante identificar aqui o que se configura como sendo música em Butes, para, depois, compreender o alcance daquilo que se poderia considerar como sendo da ordem da partilha, de uma nova política para o olhar que temos sobre a música a partir de sua proposta enquanto arte de pensar.

Butes se constrói como centro, ponto de virada, de uma reflexão sobre a música, com a música, no batimento da música. $\mathrm{O}$ texto se abre com a cena originária do personagem: o 
contexto no qual Butes abandona os remos, deixa seu posto de remador de Argos, para ir ao encontro das sereias. A partir disso se estabelecem algumas balizas a partir das quais se desvelará uma nova música aos olhos do leitor ocidental.

Eles remam. Remam. Deslizam sobre o mar. A vela está firmemente presa sobre as cordas da verga. Um vento rápido os ajuda e empurra o navio. A embarcação se aproxima da ilha dos pássaros com cabeça de mulher que em grego se chamam Sereias. ${ }^{6}$

Esse incipit impõe um presente, com contornos ao mesmo tempo filosóficos e míticos, mas sobretudo musicais: trata-se de uma espécie de pulsação, marcada por um ternário insistente - o que leio como um tempo que avança e dois tempos que ficam no lugar, que aprofundam sincronicamente o que supostamente seria o "avançar" no tempo com o tempo da música. No momento em que Butes vai ao encontro da música, o desejo está a ela associado:

Butes nada vigorosamente de tanto que seu coração arde de desejo de ouvir, escreve Apolônio, as vozes agudas das passarinhas com cabeças e seios de mulher que atraem seu corpo teso e úmido. (...) Ele já vai abordar à ilha que canta; literalmente a margem 'cantando', a terra encantatória (...). ${ }^{7}$

É esse canto que se deve escutar, ouvir. Esse canto é um chamado que produz um ato sobre o corpo de Butes, que o impele a pular. É a entrada do canto na retomada da narrativa de Butes que parece determinar a natureza da música que emerge nesse texto. Butes deixa de ser o "infeliz" de Argos de Apolônio, infeliz porque se joga no mar e nele morre, para se tornar aquele que obedece - porque a verdadeira escuta é da ordem da obediência - à música, que se revela associada ao desejo:

"Ouvir é obedecer. Escutar se diz em latim obaudire. Obaudire derivou em francês na forma de obéir, obedecer. A audição, audientia, é uma obaudientia, é uma obediência." 8

O que seria obedecer a uma voz? Deixar-se levar pelo Outro? Instaurar esse grito do outro em si? Quais seriam os caminhos dessa mobilização do corpo, desse ato, na relação com essa voz ouvida? A voz que se ouve é mesmo a de um Outro?

Como nos outros textos de Pascal Quignard, o leitor se confronta com as origens. No tocante às origens da música - desvio para pensarmos essa voz que chama como voz originária -, o episódio de Butes se constrói como oposto ao de Ulisses, que se faz amarrar para não sucumbir ao canto das sereias. Ulisses e seus remadores de orelhas tapadas de cera, protegidos pelo ruído ensurdecedor do plectro de Orfeu - "Apolônio escreve que essa peça de Orfeu é tão estrondosa que as orelhas ressoam com o próprio ruído do plectro" ${ }^{-}$-, torna-se uma questão central:

"Agora a intensidade e a beleza da melodia dos pássaros parece recuar no mar. Agora os cinquenta heróis não ouvem mais com clareza esse canto siderante". ${ }^{10}$

Enquanto a peça de Orfeu é ruidosa, o canto das sereias é siderante, chamador, aderente. Peça musical versus canto. É sobre essas palavras, essas duas noções, que se constrói a noção de música: ruído produzido por meio de instrumentos fabricados, a música órfica, discursiva quase, organizada, de um lado, e o canto siderante, vocal, primitivo, originário das sereias, dessas mulheres-pássaro que fazem parte de nossos mitos originários, do outro, cuja presença permanece hoje enquanto pregnância, ou latência, a presença no presente, esse outrora que nos envolve: 
"Em toda música há um chamado que ergue, uma somação temporal, um dinamismo que abala, que faz deslocar, que faz levantar e ir na direção da fonte sonora."11

Música como chamado, música como somação temporal, como dinamismo que faz ato no sujeito, que mobiliza o corpo, que produz um movimento, uma reação. Não se trata, portanto, da música à qual estamos habituados, a música ocidental, que é preciso ouvir ou, ainda, tocar, "executar":12

Até mesmo Orfeu o Músico nada quis ouvir desse canto contínuo.

Ulisses foi o primeiro a querer ouvi-lo. Tomou a precaução de mandar amarrar os pés e as mãos ao mastro de seu navio.

Só Butes pulou. ${ }^{13}$

Qual é, então, o canto que não queremos ouvir, que nos proibiram de ouvir, que é contracantado pela música instrumental? Trata-se do canto que chama, um canto contínuo, que já estava e continuará a estar, o canto que ergue o corpo, oposto à música que o assujeita, constrangendo-o à audição em posição sentada:

\footnotetext{
Quando Butes solta seu remo, ele se levanta.

Quando Butes sobe ao convés, pula.

Butes dança.

Quando Orfeu sobe ao convés, ele se senta. Sentado, toca sua cítara com o plectro. Ele contra canta o canto de Ligia, de Leucósia, de Parténope. Apolônio diz que ele afasta o canto delas, que tenta encobrir o chamado de suas vozes com um ritmo extremamente retumbante e acelerado até que suas orelhas ressoem com o ruído do plectro. ${ }^{14}$
}

A oposição entre a música, o discurso organizado, ritmado, controlado, afinado, resultante da fabricação do homem, vem perturbar algo que estava já presente e que mobilizava o corpo: o canto contínuo. Mais do que oposição, trata-se de produzir um obstáculo, de impedir que o homem obedeça a esse canto:

(...) a música da cítara fabricada pela mão do homem faz obstáculo à potência siderante do canto animal.

O que traduzo por canto animal, Apolônio chama de akritos aulos. Voz 'acrítica' quer dizer não separada, indistinta, contínua.

Logo depois, Apolônio acrescenta o adjetivo 'aguda'.

$\mathrm{O}$ canto acrítico é necessariamente soprano pois vem do mundo em que a vida se desenvolve.

$\mathrm{O}$ mundo em que a vida se desenvolve é o mundo unicamente feminino que não conhece a muda tal como a conhece o mundo dos homens. ${ }^{15}$

Essa muda, esse canto soprano que faz tanta falta e que só pode ser representado pela mulher, ligado à origem, às origens, já nos fora apresentado em Todas as manhãs do mundo: na figura da muda constitutiva do personagem Marin Marais, certamente, mas também, e principalmente, na retomada de Mozart, que adentra o mundo da composição no momento da crise profunda desencadeada por sua própria muda, da voz infantil, do canto soprano que fazia um com a mãe, perdido para sempre na adolescência do homem. A música órfica, dominante no ocidente, a mesma que será associada ao Holocausto por Primo Levi, retomada em $O$ ódio à música, tem a ver com a perda, com o não retorno possível à origem, à animalidade.

O pensamento de Apolônio é claro. A seus olhos há duas músicas. Uma de perdição (que ele define admiravelmente dizendo que ela impede o retorno), a outra órfica, salvífica, articulada, coletiva, que é aquela que obtém sua unanimidade e que, assim, garante a rapidez aos remos dos remadores. ${ }^{16}$ 
A música instruída é da ordem do social, do maquinal. A música que Pascal Quignard compartilha é a da perdição, na medida em que está ligada ao desejo. É uma escuta específica que só é possível se nos tornamos um pouco surdos, se o sujeito aceita ouvir, como o fazia na vida intrauterina, onde todos os ruídos se confundiam, com a voz da mãe. O mar, a água e as sereias parecem, portanto, uma metáfora ideal:

$$
\begin{aligned}
& \text { "O canto que se realiza antes da língua articulada mergulha - simplesmente } \\
& \text { mergulha, mergulha como Butes mergulha - no luto da Perdida". }{ }^{17}
\end{aligned}
$$

Os sons que a criança ouve não nascem no instante do seu nascimento. Muito antes que possa emiti-los, a criança começa a obedecer à sonata materna ou ainda incognoscível, preexistente, soprano, abafada, quente, envolvente. ${ }^{18}$

É o risco que se deve correr: o de perder, perder tudo, perder a vida, a vida de antes, a vida que se poderia ter tido. É preciso abandonar tudo, viver a dor, viver a separação na linguagem, pois a entrada na linguagem pressupõe a separação do corpo materno: "Onde o pensamento tem medo, a música pensa."19

Em um mundo que nos propõe produtos para todos os males, remédios para todas as dores, Pascal Quignard nos propõe um mergulho de cabeça na dor, na perdição, na incomunicabilidade, para a escuta do canto acrítico, o canto que já estava lá antes que respirássemos na terra, antes que estivéssemos submetidos à língua materna e implicados na tradução desse canto animal, que jamais poderia ser organizado. A música é a única que nos permite pensar a perda advinda do nascimento.

O texto insiste no presente, nos três tempos, os tempos que se sobrepõem. Trata-se de tempo e não de ritmo, pois este sempre pode ser escandido, previsto e relacionado à audição sentada:

\begin{abstract}
A música grega, logo romana, logo cristã, logo ocidental tornou-se cada vez mais conjuratória. Ela se tornou extraordinariamente instrumental. A música ocidental sacrifica a dança originária, que, no entanto, pertence ao núcleo arcaico. É primeiramente o abandono do transe, depois a renúncia a abandonar o posto de remadores que autorizaram sua escritura. Que explicam sua execução sentada, mas, sobretudo, sua inexplicável e por assim dizer 'onírica; inibição muscular - sua prodigiosa audição sentada. ${ }^{20}$
\end{abstract}

Esse mergulho também é dado pela escritura. O que se constrói no início como texto organizado em uma resposta à demanda social, o texto para o debate proposto pelo jornal, torna-se um mergulho escritural complexo, a escuta de um canto originário: o texto empreende uma rota original com a incursão daquele que escreve em seu primeiro tempo, em um momento que precede a escritura, que a coloca como fuga da música. Ele propõe à escritura a mesma questão formulada para a música. De crítica a uma música instrumental, retomada em $O$ ódio à música por meio do personagem de Apolônio, a narrativa se torna incursão no momento em que a música é deixada em suspenso e em que a escritura acaba suspendendo a identidade daquele que escreve, daquele que deveria ter sido músico, mas que se tornou escritor. Ou ainda, o momento em que o escritor acaba fechando o ciclo para reencontrar-se com a música por meio do desejo da escritura.

Mas como se constitui essa escritura na relação com o caráter pulsional da voz e de seu chamado? Em Pascal Quignard, o ritmo, significado fortemente pelas repetições tanto de 
imagens como de palavras, por exemplo, tanto em um só texto como no conjunto de seus textos, parece apontar para uma emergência da voz na fissura da escritura. Essa fissura, presente no estranhamento do emprego que faz do aoristo grego, mas também na apropriação de certa sintaxe latina em língua francesa, é o que parece produzir incômodo, interpelando o leitor a parar para ouvir, mas interpelando também aquele que escreve e que precisa ouvir. As "quedas" ("chutes", fragmentos escritos no âmbito de um projeto, abandonados, decaídos, e depois, eventualmente, retomados em outros projetos), o EU empregado sem aviso, sem preparação, os tempos verbais perfeitos (presente e pretérito) que se amalgamam em um aquiagora (hic et nunc), apontam para uma emergência enunciativa na escrita. Uma escrita da obediência, do ato de ouvir assujeitado, que cede um corpo que ainda pode escrever, pois está vivo, aos que já se foram, ao que já passou, mas que deixou marcas nesse corpo, cujos movimentos, cujas pulsões, carregam os rastros, as marcas desse passado indelével, porque presente.

As palavras conservam uma quantidade incrível de vestígios do que foram além da voz. As palavras conservam até mesmo imagens. (...) Começo há quatro mil anos. Outrora a velha letra Aleph era o rosto de um touro visto de frente. Os chifres caem um pouco. Alf em fenício dá nome ao touro. Alf, Aleph, alpha, a cai para a direita. É 'alpha' em grego. Quatro mil anos passam... A cabeça de touro, como se vê, não desaparece em quatro mil anos. Ao final de quatro milênios ela perde apenas um pedaço de seu chifre esquerdo. E temos agora ' $a$ '. ${ }^{21}$

O repertório, a erudição, o fundo intelectual, não estão mais presentes enquanto resgate, como pretendia Flaubert e que implicava um distanciamento. Tudo isso é re-vivido numa atividade predatória que amalgama passado e presente sem hierarquização (atente-se para o fraseado econômico, para as orações sem subordinação, para o fragmento estelar da escrita de Pascal Quignard).

Ao aceitar a publicação dos manuscritos, o escritor retoma sua crítica da música órfica, da audição sentada, para abandonar por um instante a proteção que seu nome de autor lhe confere, que o texto, protegido por suas capas, propõe enquanto organização, estabelecimento, "leitura sentada".

Nunca "sentada", a leitura de Pascal Quignard faz ato, ato de escrita, acompanhando a própria iniciativa de escritura: "O desejo de escrever um livro: o desejo de ler um livro."22

A leitura, que chama a voz da escrita, desencadeia uma escritura a partir do silenciamento. Para escrever, o escritor deve se calar: "Escrever. 'Falar de perto' 'calando-se'.

A oferenda. ${ }^{23}$

Calar-se significa primeiramente arrancar-se à surdez na qual estamos com relação à linguagem em nós e na qual o locutor está totalmente imergido no círculo social, rítmico, ritual. A linguagem nunca se ouve ao falar: ela se produz ultrapassando sua escuta. O locutor fica boquiaberto na abertura de sua perda resfolegante e na fuga para frente da boneca ou do fetiche do seu propósito. ${ }^{24}$

Assim como a música, a escritura chama. Escrever é invocar, é surpreender em pleno voo outros textos, textos de antes, como uma ave de rapina, como um predador, como Diana, é fazer ouvir esse outrora da escritura escrevendo. Escrever implica uma partilha, mas uma partilha que depende de um recuo com relação ao social, ao e do canto animal, do batimento rítmico interno da enxaqueca, da dor, que a crítica faz ato, que produz o ponto surdo 
necessário a nossa escuta demasiadamente condicionada, que a crítica nos permite mergulhar. De contornos muito políticos, Butes não propõe uma reflexão sobre a música, mas com a música, como o faz com a escritura, com o tempo irrecuperável, com a memória, com a origem imemorial, mas pregnante enquanto ato de invocação permanente:

\author{
Três escólios. \\ 1. Não se recupera o tempo. (Mas todo morto se come e é recuperado no seguinte \\ sentido: alimentando-se do que nele se destrói. A morte, para os carnívoros, é, de \\ fato, a única alimentadora.) \\ 2. Esse movimento irrecuperável não orienta. (Simplesmente não pode mais não \\ chegar aonde não poderia não ter ido.) \\ 3. A origem se segue no tempo. (O caráter irrecuperável do outrora funda a \\ irreversibilidade na insuficiência de todo agora. $)^{25}$
}

É um trecho que, nos manuscritos, desencadeia uma mudança radical no texto, que ordena o emprego do presente (tempo modificado entre versões), que inscreve a reflexão sobre o tempo na escuta e nesse canto. A escolha do presente em detrimento do passado é o silenciamento com relação à narrativa organizada da experiência e que se abre à emergência dessa voz enunciável. O escólio é essa sobra de voz de outrora em detrimento da retomada discursiva do passado, que seria fatalmente ordenada, controlada. Trata-se da escuta que encerra o inatingível, o impulso, a dança, a música que impele o corpo, que o mobiliza. $\mathrm{O}$ texto propõe espaços para essa atividade:

\footnotetext{
"Raros, muito raros, são os humanos que se jogam na água para reencontrar a voz da água, a voz infinitamente longínqua, voz que nem é voz, o canto ainda não articulado que vem da penumbra.

Alguns músicos.

Alguns escritores mais silenciosos que outros em páginas ainda mais mudas."26
}

Obedecer ao desejo, no sentido de lhe emprestar os ouvidos, significa estar na música. Dançar, permitir que o corpo reaja, significa estar no desejo. Escrever significa estar no desejo, fazer com que essa voz deixe de ser um chamado prospectivo e que passe a mobilizar o sujeito que, aqui, se inscreve na escritura.

Mas não se trata de uma música qualquer, de uma dança qualquer, de uma audição qualquer:

Falo de uma verdadeira escuta. Ou seja, da obaudientia de uma verdadeira audientia. Das escutas verdadeiras, acho que o homem conhece apenas duas: 1. A leitura dos romances, pois a leitura de um ensaio não suspende nem a identidade nem a desconfiança, 2. A música erudita, ou seja melos compostas para aqueles que passaram pela iniciação da linguagem individual silenciosa. Essas são duas formas de audição cuja disponibilidade silenciosa se coloca em postura de ser totalmente, mas também individualmente, afetada. ${ }^{27}$

Outra vez o silêncio, o silenciamento, a "disponibilidade silenciosa", necessários à verdadeira escuta. Como silenciar?

Butes, de Pascal Quignard, comparado, como sugerem os manuscritos, às Sereias de $K a f k a$, reenvia a esse silêncio que permite ao silêncio de nos envolver ao mesmo tempo em que nos obriga a obedecer ao batimento interno. No episódio de Kafka, o texto sugere que o canto ouvido por Ulisses consistia no mais profundo silêncio. Como Butes, as sereias de Kafka são dançarinas. Michel Vivès (2009), ao reler o episódio de Kafka, propõe uma reflexão sobre 
a invocação que vai ao encontro, por meio da psicanálise, do problema figurado, proposto pela retomada que Pascal Quignard faz do personagem de Apolônio. Assim como Pascal Quignard, ele reconhece o retorno do batimento, ao que em Butes leremos como "autocalmente de base dois", o "fort-da" freudiano.

Os ouvintes abandonam a identidade ao mesmo tempo em que abandonam a oralidade: eles se silenciam. Para quem lê um romance, assim como para quem escuta música, terra em que se pode apoiar os pés é uma forma de fazer-silêncio. A imersão do mergulhador de boca fechada no mar do silêncio. ${ }^{28}$

Fazer-silêncio, uma condição dessa obaudientia, que associo ao que Vivès desenvolve como "ponto surdo da psique":

\begin{abstract}
"Ponto surdo que eu defino como o lugar onde o sujeito depois de ter entrado em ressonância com o timbre original deverá ser capaz de ensurdecer para falar sem saber o que diz, isto é, como sujeito do inconsciente..$^{29}$
\end{abstract}

Não se trata de ouvir a voz para narrar a experiência, pois para aquele que ouve a voz não haveria retorno. Mas, como no caso da obediência da escritura, produzir um ponto surdo que permite, no caso da proposta quignardiana, uma emergência da voz nesse jogo de fort-da com as origens das relações entre voz e escrita. Saber que o canto está lá, outrora, e a voz que pode emergir só é possível no aqui/agora. A voz não aparece, tampouco sei se poderia aparecer, mas a fenda aberta pela presença presente do contar, da enunciação do contar, pelas repetições de toda ordem, pelas estranhas aparições do EU, produzem um tensionamento da escrita enquanto materialidade exclusivamente relacionada ao olhar, figurando o que leio como emergência da voz, mas também de uma problematização da enunciação, em que a dicotomia significante-significado fissuram as possibilidades de distanciamento daquele que fala com relação àquele que escreve. Não há possibilidade de transposição entre a língua falada e a língua escrita, pois, como nos propõe Benveniste, há uma "linguagem interior":

Pois o ato de escrever não procede da fala pronunciada, da linguagem em ação, mas da linguagem interior, memorizada. A escrita é uma transposição da linguagem interior, e é preciso primeiramente aceder a essa consciência da linguagem interior ou da 'língua' para assimilar o mecanismo da conversão em escrito. ${ }^{30}$

O tensionamento enunciativo produzido pela escritura com a voz, que pensa com a voz, vem justamente problematizar a emergência da enunciação no escrito. Para que a enunciação tenha lugar, não se pode prescindir do corpo, o que pressupõe que o corpo também tenha que ser repensado. $\mathrm{Na}$ escrita de Pascal Quignard, não temos um corpo, teórico, objeto de escrutínio, de exploração, uma ideia de corpo. Temos o corpo daquele que escreve, que, afetado pelo escrito, pelo já escrito antes, pela escritura em curso, se vê obrigado a emergir, a significar o problema dessa emergência no que ela tem de mais problemático: a impossibilidade de sua presença enunciativa no escrito, figurado na insistência do presente, assim como na irrupção nunca construída discursivamente do EU. A impossibilidade da presença no escrito deve-se à impossibilidade de uma enunciação do ato de fala, do aqui/agora do sujeito que toma a palavra para dizer EU. No entanto, muitas são as passagens de Pascal Quignard em que o que chamei de 'irrupção do EU' apontam justamente para essa insuficiência na escrita, abrindo, mais uma vez, a ferida da escrita: sua fragilidade enunciativa e sua natural propensão à discursividade e a um pretérito controlado pelo sujeito que escreve. Ora, para 
Pascal Quignard, o pensamento está justamente na falta de discursividade, na fragmentação, ou na falha da discursividade.

O problema que se coloca, portanto, para a literatura é central: como narrar? Como narrar depois da morte? As sereias não narram, pois o canto das sereias é animal, não articulado. Será que poderíamos continuar narrando essas grandes experiências sem a observação daquele que, como o herói, só observou? Só testemunhou? O testemunho é realmente possível? Uma literatura de testemunho é realmente possível?

Em Mourir de penser (2014), Pascal Quignard retoma as relações entre o mergulhador de Paestum e a morte:

\begin{abstract}
O pensador, confrontado ao risco de morte psíquica, é um mergulhador de Paestum que se joga no mar Tirreno. Ele mergulha em uma diacronia de alguma forma maior do que aquilo que sincroniza o que chamamos de atualidade. Ele mergulha em um tempo maior que o espaço geográfico, em um abismo anacrônico mais profundo que a sequência histórica ordenada em torno do momento em que ele nasceu até o dia que vem na hora que segue. A partir do abismo traumático, ele se perde que algo maior do que o si-mesmo. Esse 'mundo maior que o si-mesmo' se perde em um mundo tão vasto quanto o útero da mãe era para o marulho dos primeiros instantes. A Perdida é o objeto. A Perda é o chamado. Perder-se com a perdida é o que designa o verbo meditar: perder-se no objeto. ${ }^{31}$
\end{abstract}

Estamos diante de uma escritura que problematiza fortemente sua própria condição ao fazer emergir, tanto na forma (penso aqui no ritmo, no emprego dos tempos verbais, mas também no fragmento), como no que ainda precariamente continuarei a chamar de fundo: os temas, as imagens, as ideias, seu problema central: quem enuncia?

Talvez, fosse até mais honesto não pensar em uma questão em si, mas em uma emergência. A escritura de Quignard, às voltas entre origem e morte, na busca das vozes originárias e das sombras errantes, nos interpela. Aponta o dedo, mas dessa vez não para a própria máscara (como antes sugeriu Barthes para tratar do artifício realista), mas para a potência da voz na letra. Alguém enuncia, mas a empreitada enunciativa é sempre complicada na escrita; ${ }^{32}$ mas Pascal Quignard, ao escrever numa forma e num ritmo que produzem um ato no leitor, acaba criando possibilidades para que sua própria voz figure essa emergência, ou que se figure como emergência.

\title{
Referências bibliográficas
}

BENVENISTE, Émile. Últimas aulas no Collège de France 1968 e 1969. [trad. varios] São Paulo: Ed. da Unesp, 2014.

FENOGLIO, I. e Galíndez-Jorge, V. Pascal Quignard. La littérature hors frontières. Paris: Hermann, 2014. QUIGNARD, Pascal. Mourir de penser. Paris: Grasset, 2014.

Butes. São Paulo: Dobra Editorial, 2013.[trad. Verónica Galíndez-Jorge]. La leçon de musique. Paris: Gallimard, 2002 (1987). La haine de la musique. Paris: Gallimard, 1997 (1996).

Petits traités. Paris: Gallimard, 1997 (1981)

QUignard, P. e FENOGLIO, I. Sur le désir de se jeter à l'eau. Paris: PSN, 2011.

VIVÈS, Jean-Michel. O silêncio das sereias de Kafka: uma aproximação literárias da voz como objeto pulsional. [trad. Robson Lacerda Dutra]. In. O Marrare, n. 11-2009, disponível on line: http://www.omarrare.uerj.br/numero11/pdfs/robson.pdf (consultado em 25/11/2014] 


\section{Notas de fim}

${ }^{1}$ Quignard, Pascal. Butes. [Trad. Verónica Galíndez-Jorge] São Paulo, Dobra Ed.: 2013 [2008], p. 8

${ }^{2} \mathrm{O}$ emprego do termo nada tem de casual, pois remete à bobina de fio vermelho que Ariadne oferece a Teseu, que só narra seu retorno ao renovar a bobina de linha vermelha. Narrar, passa a ser refazer um percurso com a bobina, mas o fio já está desenrolado. Quignard também emprega o termo "bordar" para a forma como conta histórias em Todas as manhãs do mundo e La leçon de musique.

${ }^{3}$ Idem, p. 7.

${ }^{4}$ Idem, p. 12.

${ }^{5}$ Idem, p. 12.

${ }^{6}$ Idem, p. 3.

${ }^{7}$ Idem, p. 5.

${ }^{8}$ Quignard, Pascal. La haine de la musique. Paris: Gallimard 1997 [1996], p. 108

${ }^{9}$ Butes, Op. cit., p. 4.

${ }^{10}$ Idem, p. 4.

${ }^{11}$ Idem, p. 6.

12 E que invariavelmente me remete à rigidez pós romântica da execução da partitura "original", da "execução original" e que pressupõe o assujeitamento daquele que toca. Lembro-me, ainda, do depoimento de Nelson Freire, no documentário sobre sua vida e obra, em que fala nostalgicamente de seu desejo de tocar livre e alegremente, como no jazz.

${ }^{13}$ Idem, p. 7.

${ }^{14}$ Idem, p. 9.

${ }^{15}$ Idem, p. 9.

${ }^{16}$ Idem, p. 10.

${ }^{17}$ Idem, p. 3.

${ }^{18}$ Quignard, Pascal. La haine de la musique. Paris: Gallimard 1997 [1996], pp. 108-109

${ }^{19}$ Butes, Op. cit., p. 11.

${ }^{20}$ Idem, p. 21.

${ }^{21}$ Resposta de Pascal Quignard a Leda Cartum, transcrita em Fenoglio, I. e Galíndez-Jorge, V. (2014:203-204)

${ }^{22}$ Quignard, Pascal. Petits Traités. Paris: Gallimard, 2002 [1990], p. 59.

${ }^{23}$ Idem, p. 56.

${ }^{24}$ La haine de la musique, Op. cit., p. 128.

${ }^{25}$ Butes, Op. cit., pp. 40-41.

${ }^{26}$ Idem, p. 62.

${ }^{27}$ La haine de la musique, Op. cit., pp. 129-130.

${ }^{28}$ Idem, pp. 130-131.

${ }^{29}$ Vivès, Jean-Michel. O silêncio das sereias de Kafka: uma aproximação literárias da voz como objeto pulsional. [trad. Robson Lacerda Dutra]. In. O Marrare, n. 11-2009, disponível on line:

http://www.omarrare.uerj.br/numero11/pdfs/robson.pdf (consultado em 25/11/2014], p. 6

30 Benveniste, Émile. Últimas aulas no Collège de France 1968 e 1969. [trad. varios] São Paulo: Ed. da Unesp, 2014, p. 132.

${ }^{31}$ Quignard, pascal. Mourir de penser. Paris: Grasset, 2014, p. 54

${ }^{32}$ Penso em todo o debate gerado a partir de Derrida, Benveniste, Zumthor. 